\title{
Corporate Social Responsibility as Core Competence for the Business Model of Social Start-Ups in the Netherlands
}

\author{
By Herman T. Wevers ${ }^{1}$, Cosmina L. Voinea ${ }^{2}$
}

\begin{abstract}
Little is known about how social enterprises and social start-ups compete with the bigger players on the market. It could be reasoned that social start-ups gain an advantage by the deployment of Corporate Social Responsibility (CSR) elements from the early beginning as a part of their core competences. The aim of this paper is to investigate if CSR elements can be a core competence and how they can contribute to the robustness of the business models of social start-ups. Data was gathered by conducting a case study and interviewing four social entrepreneurs in the first half of 2017. The data was analyzed with the help of a framework built upon the CSR pyramid, the business case for CSR and the Canvas business model. The main findings show that the CSR elements economic, ethical and discretionary responsibilities can be a core competence for social start-ups. Moreover, CSR elements can play an important role in the design of social business models. Especially the deployment of interrelationships between the CSR elements seems to be effective in designing a robust business model of a social start-up.
\end{abstract}

Keywords: Corporate social responsibility, core competences, social start-ups, business model Canvas

\section{Introduction}

'The social responsibility of business encompasses the economic, legal, ethical and discretionary expectations that society has of organizations at a given point of time' (Carroll, 1979: 500). This definition of corporate social responsibility (CSR) was formulated by Carroll for about fifty years ago, but is more topical than ever. On the one hand citizens are regularly confronted with irresponsible social behavior of enterprises, such as environmental misconduct, the violation of human rights and/or corruption. On the other hand a growing number of positive contributions through achieved through social responsible entrepreneurship can be observed. Innovative business solutions to fight poverty, improve social inclusion and/or overcome health problems are examples of these. Carroll (1979) puts the four CSR elements in a pyramid model with economic responsibilities on top. The second layer comprise the laws and regulations mentioned by Carroll (1979) as the legal responsibilities. Ethical and discretionary responsibilities come in the third and fourth layer and cover expectations of society and individual completion by the business. However, in the economic literature CSR has never been taken for granted as an aspect of doing business. Friedman (1962) argued that the only responsibility of the 
management is the maximization of profit for owners and shareholders within the rules of the game. Mintzberg (1983) concluded that the stock market will give a reward for CSR but only to a certain level. On the contrary, examples can be found in favor of CSR from the business field. The Chairman of Intel called CSR spending an investment rather than a cost (Strugatch, 2011).

CSR became more important for the business community in the last decade which is reflected in the growing number of businesses that report on their CSR activities (Habek \& Wolniak, 2013). Brønn \& Vidaver-Cohen (2008) provide us with three important motives of CSR policy. Two of them being strategic by nature: (1) legitimacy and (2) profitability. The third motive is the sustainability motive driven by personal managerial motives. Høgevold et al. (2013) investigated the concept of business sustainability and concluded that a business could gain a competitive edge, increase market share and boost shareholder value through such a sustainable approach. Carroll \& Shabana (2010) investigated the business case for CSR: 'The business case refers to the underlying arguments or rational supporting or documenting why the business community should accept and advance the CSR cause' (Carroll \& Shabana, 2010: 85). More recent Galpin \& Hebard (2015) argue that sustainability has become the strategic imperative of the new millennium. Particularly phrases such as sustainability and CSR refer to organizations enhancing their long-term economic, social and environmental performance.

Researcher has primarily addressed the question if social responsible firms do outperform or underperform compared to firms that do not meet the same social criteria (McWilliams \& Siegel, 2001). Calabrese et al. (2013) stress that the research designed to investigate the link between social responsibility and economic/financial performances has no generalizable outcome in that there is evidence of a positive correlation, a negative correlation or no correlation. To emphasize the duality in research outcomes, we mention Mao, Pearce \& Reed Wasson (2015) who showed evidence of positive CSR effects for dual mission firms. They concluded that a dual mission hybrid firm can have higher profits because of economics of scope than the benchmark pure profit firms.

Since 2000, a growing number of social start-ups are established in many countries. Startups are generally founded because three motives: wealth, independence and necessity (Hessel, van Gelderen \& Thurik, 2008, Reedy et al., 2016). However, social start-ups follow a different path to start their business (Parrish, 2010, Bocken, 2015). The social entrepreneur identifies a problem as an opportunity (Belz \& Binder, 2015) and ascertains a need or an urgency to create social impact. And while designing their social business models, these companies seem to incorporate CSR elements from all levels of the CSR pyramid simultaneously to create social impact. An example is the Grameen Bank in Bangladesh (Yunus, Moingeon \& Lehmann-Ortega, 2010, Rahman et al., 2014). This bank uses various social business models to create impact in a broad sense in the fight against poverty. Yunus, Moingeon \& Lehmann-Ortega (2010) studied these business models and propose five practical lessons, which can be applied in designing a social business model. These lessons will be used in this paper to determine the effect of CSR elements on the business models of social start-ups. This can be expressed in a certain degree of robustness of the social business model resistant to dynamic and uncertain conditions. Therefore, our central research question has been formulated as: What does the deployment of CSR elements as a core competence mean for the business model of a social start-up? 
The current paper investigates the meaning of CSR elements for the business model of a social start-up. Thereby, we aim to contribute to both the theory and practice of social entrepreneurship. Yunus, Moingeon \& Lehmann-Ortega (2010) pointed out the necessity to further study social business models for the development of self-sufficient social entrepreneurship. Moreover, by our best knowledge we could not find any research linking the CSR elements from Carroll (1979) to organizational core competences and social business models. From a practical point of view, a social entrepreneur could apply CSR elements while delivering a social business model. A business model is a rational approximation of how an organization creates, delivers and captures value (Osterwalder \& Pigneur, 2010). We argue that incorporating CSR elements as a core competence could contribute to customer advantage, uniqueness and access to new markets from the early beginning of a start-up (Prahalad \& Hamel, 1990). We expect to find that CSR elements can be deployed as a core competence which affecting the social business model design process. However, it is not sure, whether this will result in a robust and sustainable business model.

\section{The Alignment of the Concepts of CSR and Core Competences}

Carroll (1979) emphasized that literature distinguishes between CSR as a voluntary activity and CSR as an activity in conjunction with entrepreneurship. Although Devinney (2009) argued that the holy grail of CSR, doing well by doing good, is an illusion there are rationales to apply CSR in a business. McWilliams \& Siegel (2001) argued that the recognition of stakeholders interests is an important reason for a firm to create sources for CSR. However, a great variety exists in the way how social responsibility is given substance to. Carroll (1979) showed a conceptual definition for CSR, listed the reasons why CSR exists and established a philosophy about the response of businesses. Carroll defined CSR as follows: 'The social responsibility of business encompasses the economic, legal, ethical and discretionary expectations that society has of organizations at a given point of time' (Carroll, 1979: 500). We built our research upon this definition. Table 1 gives an overview of the four responsibilities and their meaning conform Carroll (1979).

Table 1: Categories of social responsibility

\begin{tabular}{|l|l|}
\hline Responsibility & Explanation \\
\hline Economic & $\begin{array}{l}\text { The fundamental responsibility of undertaking is economical. The production of } \\
\text { goods and services that society wants and sell them with a profit. }\end{array}$ \\
\hline Legal & $\begin{array}{l}\text { Society expects business to fulfil its economic mission within the framework of } \\
\text { legal requirements. }\end{array}$ \\
\hline Ethical & Expectation of society of business over and above legal requirements. \\
\hline Discretionary & $\begin{array}{l}\text { Society has no clear-cut message for business and they are left to individual } \\
\text { judgment and choice. }\end{array}$ \\
\hline Source: Own study based on Carroll (1979)
\end{tabular}

Carroll (1979) argued that these responsibilities always existed simultaneously, but that the emphasis was on economic and legal responsibilities and much less on ethical and discretionary aspects. Dubbink and Liederkercke (2009) concluded that this might be a consequence of the indistinctness on the issues in these latter two areas. As Carroll (1979) 
already stated, the response on CSR varies from doing nothing to doing a lot. And doing a lot may contribute towards a positive relationship of the business with its stakeholders. Stakeholders can have a more positive impression of the business because of discretionary activities (Brammer \& Millington, 2005).

Given our context to apply CSR elements as core competences, we agree with Michelini \& Fiorentino (2012) who argued that the traditional school of thought on CSR focuses too much on the tension between business and society rather than on their interdependence. Another important perspective for this paper comes from Devinney (2009) who reasoned that society may look at a business as an instrument for policy. In accordance with this perspective, the proactive attitude of a business with respect to CSR is important (Carroll, 1979). The Corporate Social Performance Model of Carroll (1979) implicates that a business takes a lead in the industry. In a more recent study Calabrese et al. (2013) showed a model for assessing the actual stage that a company has reached in its CSR development. The authors argued that the lack of methods to establish the current position hinders the identification and exploitation of CSR driven opportunities.

Next to the concept of CSR we have to demarcate the concept of core competences. Gökkaya \& Özbağ (2015) indicated that terms like resources, capacities and competences are redeemable applied in the literature underneath the umbrella of the concept of core competences. A relation between resources and core competences was established by Hitt et al. (2003) who argued that when resources are valuable, in possession by a few, costly to imitate and not replaceable these can be seen as a core competence. Prahalad \& Hamel (1990) gave a definition of core competences from a technical skills perspective. This definition is about the collective learning in the organization, the coordination of diverse production skills and the integration of more streams of technologies. Moreover, Prahalad \& Hamel (1990) stress the importance of combining organizational competences, a focus on maximum six core competences and the possibility to spread core competences over more business units. Core competences also may feed into more than one core product, which in return feed into more than one business unit. Gökkaya \& Özbağ (2015) proposed uniqueness, inimitability and extendibility as determiners for core competences. These are in line with the three determinants of core competences of Prahalad \& Hamel (1990) which are summarized in table 2 and will be used for analyzing our empirical data. Only when a CSR element gives substance to all three determinants it meets the requirements to be a core competence.

Table 2: Determinants of core competences

\begin{tabular}{|l|l|}
\hline Determinant & Characteristics \\
\hline 1 Customer advantage & $\begin{array}{l}\text { Valuable capacities; } \\
\text { Value creation for customers. }\end{array}$ \\
\hline 2 Uniqueness & $\begin{array}{l}\text { Distinctive relative to the competition; } \\
\text { Difficult and costly to imitate. }\end{array}$ \\
\hline 3 Potential access to the world market 1) & $\begin{array}{l}\text { Entering new markets; } \\
\text { Product usage in larger quantities within the business. }\end{array}$ \\
\hline
\end{tabular}

Source: Own study based on Prabalad \& Hamel (1990)

1) The determinant Potential access to the world market' will be interpreted Potential access to new 
markets'. It is not expected that a social start-ups get access to the world market within a few years, but they can get access to new markets.

A question that needs to be considered for the current paper is if and how the CSR elements meet the determinants of core competences. Berger et al. (2007) studied the incorporation of CSR as a concept being part of organizational culture, processes and activities. They proposed the mainstreaming of CSR in a business. Thus, a CSR strategy which is clearly present in the organization. Berger et al. (2007) came up with three models. First, there is the business case model in which CSR is only relevant if it causes competitive advantage. The second model is the social values-led model in which CSR is defined around a particular social issue. The third model is the so called syncretic stewardship model with a broad, holistic view. Berger et al. (2007) expected to find the business case model to be the most adapted model, however, this could not be proven. The connection between the CSR elements and core competences was demonstrated by Carroll \& Shabana (2010) and their business case arguments. Thereby, Carroll \& Shabana (2010) relied on the CSR pyramid (Carroll, 1979) because this model matches the best with thinking about a business case. Carroll \& Shabana (2010) proposed the so-called broad business case built upon four arguments: (1) cost and risk reduction (2) competitive advantage (3) legitimacy and reputation and (4) the creation of win-win situations for the business and society. In table 3 the arguments and an explanation of their specific contribution are listed.

Table 3: Arguments for a business case for CSR practices

\begin{tabular}{|c|c|}
\hline $\begin{array}{l}\text { Business case } \\
\text { argument }\end{array}$ & Contribution \\
\hline $\begin{array}{l}1 \text { Cost and risk } \\
\text { reduction }\end{array}$ & $\begin{array}{l}\text { - Increase long term shareholders value }{ }^{1)} \text {; } \\
\text { - Lower staff turnover; } \\
\text { - Increase of efficiency; } \\
\text { - Decrease operational costs. }\end{array}$ \\
\hline $\begin{array}{l}2 \text { Competitive } \\
\text { advantage }\end{array}$ & $\begin{array}{l}\text { - Benefits by the recruitment of personnel; } \\
\text { - Strengthen the relationship with customers; } \\
\text { - Benefits by attraction of investors; } \\
\text { - Increase competitive advantage by combining of market (external) and } \\
\text { competences (internal); } \\
\text { - Orientation competences bring philanthropically activities in line with } \\
\text { capacities and core competences. }\end{array}$ \\
\hline $\begin{array}{l}\text { 3.a Legitimacy } \\
\text { 3.b Reputation }\end{array}$ & $\begin{array}{l}\text { - Advantages by cause marketing } \\
\text { - Prove that the business is part of society } \\
\text { - CSR reporting to show consistency and compliance with social norms. }\end{array}$ \\
\hline $\begin{array}{l}4 \text { Creating win-win } \\
\text { situations for } \\
\text { businesses and } \\
\text { society }\end{array}$ & $\begin{array}{l}\text { - Connecting stakeholders interests } \\
\text { - Creating pluralistic definitions of value for multiple stakeholders } \\
\text { simultaneously. Turn a social problem into economic opportunity and } \\
\text { economic benefit, into productive capacity, into human competence, into } \\
\text { well paid jobs and into wealth. }\end{array}$ \\
\hline
\end{tabular}

Source: Own study based on Carroll \& Shabana (2010)

1) In the context of the current research we also take the value for other owners or stakeholders into account. The reason for this is that start-ups are mostly owned by their founders. Decisions about cost and risk reduction should be made considering the interest of stakeholders. 
Carroll \& Shabana (2010) assumed that there are potential threats for the viability of the business because of stakeholders' demands. They argued that the business can reduce costs and risks by offering the employees equal opportunities and by creating commitment for a responsible environmental policy. This will lead to an increase of the shareholder value in the long term. Moreover, Carroll \& Shabana (2010) argued that a proactive attitude of the business towards the environment can result in lower costs to meet current and future environmental law. Thus, societal relation management can reduce costs and risks by tax benefits and less regulation. Carroll \& Shabana (2010) stated that a business can gain competitive advantage relative to the competition by differentiation through CSR. This could lead to a cost leadership strategy and a genuine, carefully chosen CSR strategy can create an unique business proposition. As a result, most talented employees are attracted, customer relations are strengthened and the attention of investors will be drown (Carroll \& Shabana, 2010). Customers, for example, show a greater loyalty to the brand and the influx of consumers correlates positively with CSR. A lot of institutional investors search for companies with a good personnel policy, with stewardship for the environment and involvement in society (Carroll \& Shabana, 2010).

Carroll \& Shabana (2010) argued that shareholders value can increase through philanthropic activities of a business, because of the convergence of interests between economical profits and social benefits. Moreover, by putting philanthropic activities in line with the core business the focus remains intact, the efficiency of activities for charities will be emphasized, and an unique value will be created for the beneficiaries (Carroll \& Shabana, 2010). Based on Carroll \& Shabana (2010) the economic responsibilities could result in customer advantage, uniqueness and access to markets.

'Firms focus on value creation by leveraging gains in reputation and legitimacy made through aligning stakeholders interests' (Carroll \& Shabana, 2010: 99). For our current paper, we make a distinction between formal and informal legitimacy and reputation in relation to the business case argument. The formal type of 'legitimacy and reputation' of a business covers laws/regulations and CSR reporting. This argument will be mentioned as 'legitimacy' and is brought in line with the legal responsibilities of Carroll (1979). The informal type of 'legitimacy and reputation' covers the social awareness and the pursuing of standards and values. This argument will be mentioned as 'reputation' and is brought in line with the ethical responsibilities of Carroll (1979).

The formal part of legitimacy can be defined as the general perception or assumption that the actions of a firm are desired, appropriate or suitable within the social system of norms, values, beliefs and definitions (Carroll \& Shabana, 2010). This relates to existing law and regulations in a country or region and concerns labor, finance, taxes and the environment. If a company fails to apply to these rules, it may cause a negative effect on the reputation of the company. 'Companies can emphasize their legitimacy and reputation by unlocking information in relation to their achievements in the field of various environmental and social issues' (Carroll \& Shabana, 2010: 99). According to Carroll \& Shabana (2010), CSR reporting refers to stand-alone editions of social reports that include information over economic, environmental and social issues. Companies can emphasize that their operations are consistent with the social norms and expectations and that the company therefor is legitimate. Moreover, companies can apply specific laws and regulations as a part of their business. 
The informal part, according to Carroll \& Shabana (2010), considers the perception of stakeholders on how the business deals with social issues and shows her concern about society. This can lead to reciprocal relationships. Reputation can be defined as the capacity in which someone or something is known (van Dale, 1995). More specifically, reputation can be seen as an effect of the legitimacy of a business. The company shows that she is capable of running her operations and values the social norms and stakeholders interests. As an example of an ethical CSR activity aimed at legitimacy and reputation Carroll \& Shabana mention cause marketing. This is a strategy in which highlighting product advantages are connected with a call on giving to charity.

Discretionary responsibilities concern the contribution to society but from the perspective of the company. 'Synergetic value creation arguments focus on exploiting opportunities that reconcile the differing stakeholders demands. Firms do this by connecting stakeholders interest and creating pluralistic definition of value for multiple stakeholders simultaneously' (Carroll \& Shabana, 2010: 100). This may involve a wide range of activities. For example, educational activities by which recruitment possibilities are shed or the support to local communities to maintain the quality of live. Carroll \& Shabana (2010) argued that a suitable social responsibility of doing business concerns the transition of social issues into an economic chances and profit, a productive capacity, human competences, well paid jobs and prosperity. Moreover Brammer \& Millington (2005) found a positive relation between the discretionary expenses and reputation of the company.

\section{Integrating Business Models and Social Start-Ups}

Trimi \& Bergebal-Mirabent (2012) investigated business model innovation of entrepreneurship to get a better understanding of emerging developments. One of the perspectives of these authors is that starting a company is a very complex and demanding task. Trimi \& Bergebal-Mirabent (2012) argued that it is necessary for a start-up to search for a flexible and suitable business model. This is reasoned by the iterative trial and error process to come to a robust business model. The application of the business model in practice proves whether it is scalable and reproducible. Trimi \& Bergebal-Mirabent (2012) referred to the Canvas business model of Osterwalder \& Pigneur (2010) as being a conceptual instrument that supports to make the right decision at the right moment for business model developing. They emphasize that the business model Canvas can be seen as essential for the learning cycle of a start-up.

Osterwalder \& Pigneur (2010) develop the Canvas business model as a method to describe, analyze and design a business. Furthermore, they emphasize the importance of a common language to discuss strategic alternatives and innovations. The definition of a business model according to Osterwalder \& Pigneur (2010) is: 'A business model describes the rationale of how an organization creates, delivers and captures value'. This definition will be applied in this paper. Osterwalder \& Pigneur (2010) propose nine building blocks to describe the business. The central building block is the value proposition. 'This is the reason why customers choose this company instead of other companies' (Osterwalder \& Pigneur, 2010: 22). On the left side of value propositions the building blocks core activities, key partners, key resources and cost structure are positioned. These are all related to the effectiveness of the 
business On the right side of value propositions the building blocks customer relations, customer segments, channels and income flows are positioned. These are all connected to the creation of value.

In the literature no general accepted definition of a start-up as a concept could be found. Start-ups are mostly associated with innovation and young entrepreneurs. A characteristic that often appears in relation to start-ups is a product or service that changes our society or the market with a disruptive technic. To come to a demarcation of a start-up as a research unit it is necessary to narrow down general characteristics, e.g. high uncertainty and innovation. CSR elements as a core competence will initially lead to high uncertainty when a social start-up enters the market. This uncertainty concerns financial returns or finding investors. Moreover, the new and innovative aspect comes from the combination of CSR elements as a core competence and the effective combination of entrepreneurship and social impact. A definition of a start-up that connects with these factors comes from Ries: 'A human organizational form that aims at the making new innovative products and services under extremely unsettled circumstances' (Ries, 2011: 15).

The essence of a business model is in the definition of how a company creates value for customers, entices customers to pay for this value and the transformation of these payments in profit' (Teece, 2010:172). A business model is a means to compete (Trimi \& Berbegal-Mirabent, 2012). The Canvas business model can also be used for not-for-profit social companies (Osterwalder \& Pigneur, 2010). In this case the authors propose an extension of Canvas with two building blocks that show two outcomes: (1) the social and environmental costs of a business model and (2) the social and environmental benefits of a business model (Osterwalder \& Pigneur, 2010: 265). There are different approaches in the literature on how business models do work in the context of social entrepreneurship. Michelini \& Fiorentino (2012) investigated the difference between the social business model and the inclusive business model. The social business model refers to ventures that aim to solve a social problem by using business methods, while the inclusive business model embeds its origin in the bottom of the pyramid theory (BoP).

Yunus, Moingeon \& Lehmann-Ortega (2010) investigated the application of the Canvas business model in a social context. These authors defined a social business as: "[While] its primary purpose is to serve society, a social business has products, services, customers, markets, expenses and revenues like a 'regular' enterprise ... It is a no-loss, no-dividend, self-sustaining company that repays its owners' investments (Yunus, Moingeon \& Lehmann-Ortega, 2010: 311). As a conclusion they proposed five lessons based on the Canvas model from successful examples of social entrepreneurship. In these cases relative large companies realized social :impact in association with the Grameen Bank in Bangladesh. The impact is in the fields of fighting poverty, diseases and drinking water shortages. Rahman et al. (2014) described how GrameenPhone has shown concern for the poor and created a positive image and therefore is seen as a socially responsible company. The five lessons of Yunus, Moingeon \& Lehmann-Ortega (2010) are concerning the used social business models and characterize self-sufficient social business models. Three lessons correspondent to conventional business models and two lessons are specific for social business models. According to Yunus, Moingeon \& Lehmann-Ortega (2010), it is allowed that the findings of their research are generalized to all entrepreneurs who are looking for the creation of a social business. Furthermore, Yunus, Moingeon \& Lehmann- 
Ortega (2010) emphasize that the social business model scan also be applied on climate issues, pollution and energy.

Table 4: Five lessons in building a social business

\begin{tabular}{|l|l|}
\hline $\begin{array}{l}\text { Corresponding with conventional } \\
\text { business model innovation }\end{array}$ & Characteristics \\
\hline $\begin{array}{l}\text { 1 Challenging conventional wisdom } \\
\text { and basic assumptions }\end{array}$ & $\begin{array}{l}\text { - New strategies that change the rules of the game; } \\
\text { - Double loop learning. }\end{array}$ \\
\hline 2 Finding complementary partners & $\begin{array}{l}\text { - Open to other organizations; } \\
\text { - Cooperative instead of competitive. }\end{array}$ \\
\hline $\begin{array}{l}\text { 3 Undertaking continuous } \\
\text { experimentation }\end{array}$ & $\begin{array}{l}\text { - Strategic experiment as a form of knowledge; } \\
\text { - Radical changes / renewal. }\end{array}$ \\
\hline Specific for social business models & Characteristics \\
\hline $\begin{array}{l}\text { 4 Favoring social profit-oriented } \\
\text { shareholders } 1 \text { ) }\end{array}$ & $\begin{array}{l}\text { - Set up funds with a social mission; } \\
\text { - Social impact prevails over financial return; }\end{array}$ \\
\hline $\begin{array}{l}5 \text { Specifying social profit objectives } \\
\text { clearly }\end{array}$ & $\begin{array}{l}\text { - Innovative links between all stakeholders, including } \\
\text { shareholders. }\end{array}$ \\
\hline
\end{tabular}

Source: Own study based on Yunus, Moingeon \& Lehmann-Ortega (2010)

1) In the context of the current paper not only the value for shareholders has been taken into account but also the value for the founders, entrepreneurs or important stakeholders.

The design of a business model is an incremental and iterative process in which learning and adaptation contribute to success (Shafer et al., 2005; Trimi \& Berbegal-Mirabent, 2012). In a broader context, Høgevold et al. (2013) stated that the planning, implementation and evaluation of sustainable business models seems to be an ongoing learning process that generates valuable knowledge. Because starting up a business a complex and demanding process, the search for a flexible and suitable business model is essential for every start-up (Trimi \& Berbegal-Mirabent, 2012). Yunus, Moingeon \& Lehmann-Ortega (2010) argued that continuously experimenting contributes to the knowledge and new courses to give substance to the business. They mentioned the concept of double loop learning in which feedback from the output leads to adaption of the originally starting points. This might also the case for social start-ups as a strategy for survival. Trimi \& Berbegal-Mirabent (2012) argued that the application of the Canvas business model is essential for the learning cycle of a start-up for four reasons. First, it is a practice in constant reflection for the entrepreneur. Second, it provides insight in the consistency between the different components and stakeholders which may lead to new business ideas. Third, it forces the entrepreneur to look at the business in a holistic way. And finally the graphical display contributes to the creativity and innovation in relation to the business.

\section{Methodology}

Based upon our literature research we created a conceptual framework outlining our assumptions about (1) deploying the four CSR elements of Carroll (1979) as a core 
competence of a social start-up and (2) including the CSR elements as core competences into the building blocks of the Canvas business model (Osterwalder \& Pigneur, 2010). Accordingly, we formulated seven propositions which will be tested by data we gain from four case studies.

Proposition 1 CSR element economic responsibilities, business case argument cost and risk reduction, can be applied as a core competence of a social start-up.

Proposition 2 CSR element economic responsibilities, business case argument competitive advantage, can be applied as a core competence of a social start-up.

Proposition 3 CSR element legal responsibility, business case argument legitimacy, can be applied as a core competence of a social start-up.

Proposition 4 CSR element etbical responsibility, business case argument reputation, can be applied as a core competence of a social start-up.

Proposition 5 CSR element discretionary activities, business case argument creating win-win situations for businesses and society, can be applied as a core competence of a social start-up.

Proposition 6 The application of CSR elements as a core competence of a social start up can contribute to a robust business model of a social start up.

Proposition 7 The learning process of a business model design and strategic experiments can lead to adaptation of the original social starting points.

\subsection{Data collection}

The data for our research was collected by means of a multiple case study. To conduct this qualitative study, we selected four Dutch social enterprises from the angle of literal replication. The first step in the selection process was compiling a short-list with potential social enterprises which met the definition a social business of Yunus, Moingeon \& Lehmann-Ortega (2010). In the next step we applied the criteria for case study selection: (1) the social enterprise was situated in a start-up stage, (2) the company's founding year may be at a maximum of ten years back, (3) the year of founding differed from the other social enterprises and (4) the field of play differed from the other social enterprises. We expected social enterprises and their business models to evolve in similar ways, but only to a certain extent. Because of the different stages of the start-up phase, we also expected to find deviations between the cases. Moreover, operating on different markets is expected to affect the individual social business models.

We conducted four in-depth semi-structured interviews in the period between February and April 2017. We interviewed one respondent per start-up guided by an interview protocol. The interview protocol included following sections: (1) opening and introduction, (2) CSR and the core competences, (3) CSR and the business model, (4) iteratively design of the business model and (5) closing. The section on CSR and core competences included questions on the economic, legal, ethical and discretionary responsibilities and if/how these are an advantage for a social enterprise. The section on CSR and the social business model included questions on how the efficacy of the Canvas business model building blocks can be strengthened by CSR propositions. The section of the iteratively business model design process was meant to discuss if/how the current business model was sufficiently robust to hold in spite of the changing business environment. Interviews took between one and two hours, were recorded with permission and literally transcribed. Before further processing, the transcriptions were send to the 
respondents for review and validation. Table 5 gives the main characteristics of the social start-ups and the respondents. Next to the interviews, we used impact reports by the startups if available to complement the data.

Table 5: Description of selected case study enterprises and interviewees

\begin{tabular}{|c|c|c|c|c|c|}
\hline Casus & $\begin{array}{l}\text { Year of } \\
\text { Estab- } \\
\text { lishment }\end{array}$ & $\begin{array}{c}\text { Employees } \\
\text { (not fte) }\end{array}$ & Core business & Mission & Respondent \\
\hline S1 & 2014 & 16 & $\begin{array}{l}\text { Sustainability of } \\
\text { sports clubs. }\end{array}$ & $\begin{array}{l}\text { Our mission is to leave } \\
\text { behind the world in a } \\
\text { better state than we } \\
\text { found her. This means } \\
\text { that we have to realize } \\
\text { sustainable impact. }\end{array}$ & $\begin{array}{l}\mathrm{R} 1 \text { is one of the } \\
\text { founders of } \mathrm{S} 1 \\
\text { and also owner of } \\
\text { the company. }\end{array}$ \\
\hline S2 & 2016 & 16 & $\begin{array}{l}\text { Montage and } \\
\text { assemblage activities } \\
\text { for people with a } \\
\text { backlog on the labor } \\
\text { market. }\end{array}$ & & $\begin{array}{l}\mathrm{R} 2 \text { is one of three } \\
\text { initiators of } \mathrm{S} 2 . \\
\text { His portfolio is } \\
\text { general affairs. }\end{array}$ \\
\hline S3 & 2011 & 6 & $\begin{array}{l}\text { Fishing plastic waste } \\
\text { from the Amsterdam } \\
\text { Canals as an outing. }\end{array}$ & $\begin{array}{l}\text { Our mission is the } \\
\text { removal of plastic from } \\
\text { the world waters. }\end{array}$ & $\begin{array}{l}\mathrm{R} 3 \text { is project } \\
\text { manager at } \mathrm{S} 3 .\end{array}$ \\
\hline S4 & 2010 & 40 & $\begin{array}{l}\text { Coffee bars/ } \\
\text { lunchrooms as } \\
\text { training sites for } \\
\text { people with a back } \\
\text { log on the labor } \\
\text { market. }\end{array}$ & & $\begin{array}{l}\mathrm{R} 4 \text { is one of the } \\
\text { founders of } \mathrm{S} 4 .\end{array}$ \\
\hline
\end{tabular}

Source: Own study of selected enterprises

\subsection{Data analysis}

The collected data was structured by the three key concepts of which we expect that they may be interrelated: CSR, core competences and the business model of a social start-up. The data has been analyzed by using the coding methods of Boeije (2014). First the application of CSR elements as a core competence were investigated. The propositions P1 up to and including P5 were operationalized by the arguments of Carroll \& Shabana (2010). Therefore, every CSR element was linked to one or two arguments (table 3). Economic responsibilities were connected to the two arguments Cost and risk reduction and Competitive advantage. The legal responsibilities were connected with the argument Legacy. The ethical responsibilities were connected with the argument Reputation. The discretionary responsibilities were connected with the argument Creation of win-win situations for business and society. The outcomes have been qualitatively measured against the scale of core competences (table 2).

The operationalization of $\mathrm{P} 6$ was done per building block of the Canvas business model (Osterwalder \& Pigneur, 2010). For every building block Osterwalder \& Pigneur (2010) described specific characteristics which we applied as indicators. To measure the effect the 
outcome of the interviews were coded and put in a table per case with all building blocks. The outcomes have been qualitatively measured against the scale of the five lessons of Yunus, Moingeon \& Lehmann-Ortega (2010).

The operationalization of P7 was done by the concept of double loop leaning as mentioned by Yunus, Moingeon \& Lehmann-Ortega (2010). We asked the respondents about their experience in adapting the social business model to the dynamic business environment, but also the impact of financial issues on the business model.

\section{Results}

The results of the data analyses can be divided into two main sections. The first section provides the results of the application of CSR elements in the core competences of the four social start-ups. The CSR elements were checked with the characteristics of customer advantage, uniqueness and access to new markets. In the second section the CSR elements were examined on their influence on the building blocks of the business model. And more specifically, how this would contribute to the robustness of the business model based on the five lessons of Yunus, Moingeon \& Lehmann-Ortega (2010).

\subsection{CSR as a core competence}

Economic responsibilities, Cost and risk reduction. All four social entrepreneurs put a lot of effort to reduce costs and risks during the start-up phase. Thereby, efficiency and lean processes were leading to customer advantages at S1. A strong involvement of the employees in business processes was represented at all four cases. As a result the turnover of personnel was very low. S1 and S2 were managing lean processes and low costs in their organization. Although these approaches lead to a certain customer advantage, it does not make the social start-up unique nor gave access to new markets.

Risk reduction can also be of consideration for the customer. The existence of funds on which the start-up can rely gives the customer a better security for continuation. S1 could offer their customers security through a the guarantee of a social fund provided by the Triodos Bank. In return, the Triodos Bank performs a quality assurance on the technical installations delivered by S1 before completion. S3 gains social funding through attracting sponsors for the boats. The opportunity to rely on stable funds is a customer advantage in terms of trust, limiting risks or financing investments. It may provide the social start-up a unique position relative to the competition. However, results also show that gaining funds not necessarily provides access to new markets. Thus, the argument Cost and risk reduction of economic responsibilities is not fully confirmed to be a self-contained core competence. Economic responsibilities, Competitive advantage. Customer advantage, uniqueness and access to new markets are connected when it comes to the creation of win-win situations for the social start-up and society. This relates the discretionary responsibilities with the economic responsibilities. All founders of the start-ups had some kind background in the sector the operate now. The founders share that they have a clear vision about the necessity to change a situation by the creation of social impact. All cases are characterized by a strong value proposition because the social impact was of immediate use in practice. S1 supports sport clubs to save money by the complete implementation of sustainable electricity and lightning installations. Although with through a different approach, both S2 
and S4 support people with a distance to the labor market in finding a suitable job. Thereby S2 offers customized jobs at different employers and S4 employs people by opening coffee shops/lunchrooms in disadvantaged neighborhoods. S3 improves the environment by plastic fishing as an outing and recycling. S3 gained access to new markets through unintended side effects. Moreover, S1 is working on a different technical innovations and S3 implements the cleaning of beaches in Indonesia with a recycling system on the spot. Thus, Competitive advantage of economic responsibilities meets all determinants to be confirmed as a self-contained core competence.

Legal responsibilities. All four cases are obliged to apply to legal laws and regulations. But in case of S2 a specific law was part of the value proposition. S2 built its business upon the Dutch Participation law in such a way that this resulted in customer advantage and uniqueness. S4 gains an advantage because of their social concept when local governments have to decide upon zoning plans regulations. S4 notices that they prevail when choices for partners are made. Thus, a certain customer advantage and uniqueness was obtained from legal responsibilities. On the contrary the application of law and regulations can also lead to a certain risk. The business case of S2 could be at risk when the Dutch government decides to change the Participation law. As a part of legal responsibilities, we investigate the publication of CSR reporting/impact results. Only S1 publishes her achievements on a yearly base in the form of a banner. S3 gives information about social impact achievements, but only to their investors. Although these two social start-ups gain some kind of customer advantage and/or uniqueness by publishing their achievements, this does not built a strong case. The application of law and regulations and CSR reporting could lead to customer advantage and uniqueness. However, this does not result in access to new markets. Therefore, legal responsibilities cannot be confirmed as a self-contained core competence.

Ethical responsibilities are recognized as an effective way for social start-ups to draw customers attention their societal involvement. And more specific the involvement in local society. The activities concern a broad range of actions with the marketing like character. A combination of customer advantage and uniqueness was gained by the three more settled start-ups S1, S3 and S4. S1 spent part of their resources to create awareness at grammar schools and children. S3 puts boats at the disposal for local events or invited refuges for plastic fishing. The earnings model of S4 allowed them to offer special prices in case of social events in the local neighborhood. The youngest start-up is very strong involved in society by their core business, but spends less effort in the extra societal activities. The main reason for this was that S4 was too busy keeping the business afloat and no time was made available to set up a marketing plan. For S1 and S4 the ethical responsibilities indeed gave access to new markets. Start-up S1 made a game together with electricity network operator Liander that will be put on the market. S4 was about to open a new coffee bar/lunchroom in which people with an acquired brain injury will be trained to serve guests. Thus, ethical responsibilities do meet the determinants of being a selfcontained core competence.

The discretionary responsibilities are at aiming to create a win-win situation for the business and society. A similarity between the cases was the connection of various stakeholders with different interests by running a business. S1 connects the interests of sports clubs and local governments with sustainability. In addition the interests of the 
members of the sport clubs and the awareness about the environment were helped by the business model. S2 connects the interests of unemployed people and the industry by connecting them through the Participation law. Moreover the interests of the local government were also served by S2. S3 was able to connect the interests of many stakeholders. The people in Amsterdam want clean canals. So do the tourists. This is also in the interest of the municipality. Moreover there stakeholders like the companies and sponsors who want to do good. S4 also connects a broad range of stakeholders with their business model. These are the unemployed people, the local government, the people in the neighborhood and the property managers. The discretionary responsibilities were clearly at the base of the social business model. All cases gain customer advantages and uniqueness out of the win-win concept. Moreover S1, S2 and S3 get access to new markets by the discretionary activities. Thus, discretionary responsibilities are confirmed to be applied as a self-contained core competence.

\subsection{CSR and the business model}

Customer segments. All start-ups want to reach a target group of customers by challenging the competition with their conventional wisdom and basic assumptions. Competitive advantage as a part of the economic responsibilities is the main underlying core competence. This is done by offering sustainable solutions for specific, social problems. S1 found a complementary partner in the Triodos Bank. This partner monitors the way S1 operates, which leads to confidents by the sports clubs. Moreover start-ups S1 and S3 are undertaking continuous experimentation to create new impact opportunities. S3 started up a new enterprise which is manufacturing skateboards from the plastic waste and is looking for international solutions for the problem of plastic pollution.

Value proposition. A main finding is that all start-ups are offering a qualitative good, unique product or service that creates immediate, visible social impact. The economic, ethical and discretionary responsibilities have a powerful, synergetic contribution to the value proposition. All the business models are challenging conventional wisdom and assumptions, but also the preference for stakeholders with a social profit orientations is met. As a result the social start-ups are very different from the more conventional and/or larger companies. For instance S1 that not only gives advice about sustainability, but takes care of the complete implementation for the sports club. S2 offers customized solutions based on the Participation law instead of the usual day programs that are offered by other parties.

Channels. The preference for social-profit oriented stakeholders and the specifying of social profit objectives are the lessons that are mainly met in the business models. Ethical responsibilities are connected to channels by nature. Creating awareness can be seen as a form of social impact. In addition it creates brand awareness as a positive side effect. Also the legal responsibilities play a role in this area. S2 is a good partner for employers and local government because of their knowledge of the Participation law. Moreover, a welldeveloped and transparent CSR reporting could serve as an evaluation instrument for customers. But this was underdeveloped by most cases. Only S1 publishes a banner that is available for the public.

Customer relations. Economic, ethical and discretionary responsibilities challenge conventional wisdom and basic assumption. The preference for stakeholders with a social 
profit orientation was clearly present at all four start-ups. The social start-ups combine stakeholders interests to create win-win situations on which relationships are built. S1, S3 and S4 are well connected with their customers and stakeholders. S1 involves the clubs and the land managers in the plans. For S3 these are the interests of sponsors are important. S4 connects very well the local community in the neighborhood. Furthermore S4 is expected to be very service oriented for the companies in and around the coffee shop/lunchroom location.

Income flows. All social start-ups challenge conventional wisdom and basic assumptions as a lever to increase social impact based on the economic responsibilities. S1 for instance leverages social impact by offering free advice through which sustainability comes at reach for every sports club. The free advice is financed by the margin on the solar cells. Both S2 and S4 apply the subsidy on personnel costs. For S2 this an important part of their earnings. S4 has also smart agreements with property owners about the rent. This allows S4 to offer the neighborhood attractive prices for organizing social events. S3 offers a more conventional model in relation to the outing against a fixed price per attendee. However the sponsoring for three years of boats by companies is a challenging concept to the competition and connects S3 with social profit-oriented stakeholders.

Key resources. The main key resources deployed by the four cases are staff, finances, products/services and knowledge. Economic, ethical and discretionary responsibilities mainly challenge conventional wisdom and contribute to the preference for stakeholders with a social profit orientation. All initiators of the start-ups are very experienced in their field and a lot of professional knowledge. S1 challenges conventional wisdom by an optimized mix of skills which gives S1 operational flexibility. Moreover the quality of the solar cells and the technical installation is of high importance. S2 emphasizes the importance to have a large pool of potential employees. S4 highly values the quality of their key resources, such as coffee and other products.

Key activities. For all four cases, the key activities have a strong connection with the economic responsibilities. Thereby, they all challenge the competitions conventional wisdom and basic assumptions by solving social problems in a tangible way. The key activities have a focus towards social oriented stakeholders and are meant to solve social problems while connecting stakeholders and creating value. S1, S3 and S4 are more advanced in this process compared to S2. Being the youngest start-up, S2 has a smaller range of key activities yet. Thus, key activities seem to grow and become more mature over time. Only S1 and S3 present a mission statement that gives direction to the key activities. Key partners. Economic responsibilities are mainly incorporated in this building block. But also legal responsibilities have an impact. All start-ups cases are open to other organizations and cooperation prevails above competition. Key partners play an important role but are not necessarily social entrepreneurs. This can be a risk for instance in case of malpractice. Some of the key partners are indeed social entrepreneurs. The Triodos Bank is a key partner of S1. Moyee Coffee is the supplier of sustainable coffee for S4. But in the case of S3, non-social key partners are used to enlarge the social impact through marketing and sponsoring. Furthermore, S1 was involved in an experiment with key partner Liander to develop a game that should contribute to increase awareness and to create social impact.

Cost structure. This building block is by three out of four start-ups connected with the 
economic responsibilities. Cost structures are mainly used to challenge the competitors conventional wisdom and basic assumptions. Furthermore, a different approach between the start-ups can be identified. S1 and S2 are costs controlled. Low costs, a lean organization and efficiency are important. S3 is more value driven, because of their welldesigned products. Moreover the customers of S3 do not have a problem to pay for 'doing good'. S4 is mainly cost controlled, but tries also to create more value. This is done by serving good quality of coffee and high services.

Designing and developing a social business model involves an iterative learning process. It seems that the age of the start-up makes no difference when it comes to rethinking the social business model design. All start-ups were continuously challenging the conventional business model innovation by rethinking and adapting their own model. Experimenting with innovative products, looking for new strategic partners and entering new markets are shared entrepreneurial strategies between the four cases. However, none of the social startups considers to change their original value proposition, which endorses the strong belief of these social entrepreneurs in their business case.

\section{Discussion}

Devinney (2009) stated that the holy grail of CSR is an illusion. Although this conclusion refers to existing and often large companies, the holy grail of CSR can become a reality through the core competences of social start-ups. That is, three out of four cases did conquer a position on the market and are demonstrating organizational growth. Their targeted, hands on approach and a valuable, tangible creation of impact play an important role. Therefore, we argue that this outcome can contribute to the discussion about the existence of a business case for CSR, which is still a vexed subject in the economic literature (Berger et al., 2007, Carroll \& Shabana, 2010).

In all four cases the social entrepreneurs are, without any exception, keenly aware of the fact that it is not possible to create an impact without making profit. The value proposition should convince customers through a market of supply and demand of the need for the specific social impact. This confirms the vision of Parrish (2010) who argued the necessity of having market rewards for the contribution of the social entrepreneurs. Additionally Bocken (2015) assumed the demand of economic revenues. For the social entrepreneurs this possibility of making money from a social issue is a confirmation that the importance of their philanthropic activity is a shared vision by society. Further research on how the approach of social enterprises differ from CSR practices at existing companies could contribute to the theory and practice of CSR application.

Another insight based gained from our research concerns the ambiguous role of local governments. We observe a paradox between the responsibilities of local governments and the societal contributions of social-ups. In all four cases, local governments appreciated the contribution of the social start-ups in solving local problems. However, the local government pays too little attention to the fundamental role of governmental responsibilities in these. This leaves an intriguing question unanswered considering the rationale of social start-ups. We find that social entrepreneurs are operating in niches where the implementation of governmental policy is lacking. And thereby, the social entrepreneur is a business in the interest of the government. To find out how this 
mechanism works, further research is necessary.

\section{Conclusion}

In the introduction we advanced the thesis that the application of CSR elements as a core competence may be an advantage for social start-ups. In order to investigate this, we postulate seven propositions and tested these through conducting four case studies. Consequently, our research is limited by nature and the conclusions are valid for the included social enterprises, but we suggest to extent future research to a bigger group of social start-ups. Our research was designed to be investigate whether CSR elements can be applied as a core competence for social start-ups, thereby using the arguments for CSR practices of Carroll \& Shabana (2010). The conclusion based upon our four case studies is that business case arguments competitive advantage, reputation and creation of win-win situations for the company and society indeed can be core competences for social start-ups. On the other hand business case arguments costs and risk reduction and legitimacy do not meet the full requirements of a core competence. Thus, we can confirm propositions 2, 4 and 5 . However, proposition 1 and 3 were rejected Furthermore, we find that the interrelationship between the CSR elements may strengthen the social business model in competitive landscape.

The business case argument competitive advantage has a strong proposition mainly through the unique social impact approach of the social start-up. Customers, suppliers and local authorities are willing to cooperate because of the positive impact for instance on neighborhoods and disadvantaged people. All social start-up cases had really something to offer in here. The business case argument reputation is an important asset and a good reputation pays off in all the determinants of core competences. Cooperation and raising awareness create customer advantage. Customers at their turn are very keen on showing that they support decreasing social issues. However, reputation needs to grow and therefore, it does only provide access to new markets at later stage of start-up phase. The business case argument creating win-win situations for business and society proved to be a strong proposition if the social start-up is able to connect the interests of different stakeholders, for instance local authorities and sports clubs or social contacts in a neighborhood and disabled people. By doing so, the social start-up leverages the business results and societal impact, builds up unique business model and opens doors for new initiatives.

To meet the requirements of a core competence the arguments should meet all three determinants (customer advantage, uniqueness, access to new markets). Indeed, both business case arguments cost and risk reduction and legitimacy do lead to customer advantage and uniqueness, but do not advance access to new markets. Cost and risk reduction have a more internal organizational focus which pays off through good value for money taking into account the creation of social impact. The argument legal responsibility does also lead to customer advantage and uniqueness. However, advancing access to new markets could not be confirmed. Legitimacy concerns mainly meeting legal requirements such as local permits, national social legislation and technical standards. This strengthens reliable customer relations and uniqueness of the business proposition which in turn may lead to new customers, but it does not provide access to new markets.

Finally the learning process of the social entrepreneurs in building a business model is 
investigated. Therefore the question addressed if the entrepreneurs adapted their plans to unforeseen, difficult circumstances. The conclusion is that designing a business model is an incremental, iterative learning process for entrepreneurs. However, the original principles related to creating social impact have never been abandoned.

\section{References}

Baarda, B. et al., (2013). Basisboek Kwalitatief onderzoek. Noordhoff Uitgevers, Groningen.

Berger I.E., Cunningham, P.H. \& Drumwright, M.E. (2007). Mainstreaming corporate social responsibility: developing markets for virtue. California Management Review, 49(4), 132-157.

Bocken, N.M.P. (2015). Sustainable venture capital - catalyst for sustainable start-up success? Journal of Cleaner Production, 108(201), 648-658.

Boeije, H. (2014). Analyseren in kwalitatief onderzoek. Boom Lemma uitgevers, Den Haag.

Brammer, S. \& Millington, A. (2005). "Corporate reputation and philanthropy: an empirical analysis." Journal of Business Ethics 61, 29-44.

Brønn, P.S. \& Vidaver-Cohen, D. (2009). Corporate motives for social initiative: Legitimacy, sustainability or the bottom line? Journal of Business Ethics, 87, 91-109.

Calabrese, A. et al. (2013). Turning corporate social responsibility-driven opportunities in competitive advantages: a two-dimensional model. Knowledge and Process Management, 20(1), 50-59.

Carroll, A.B. \& Shabana, K.M. (2010). The business case for corporate social responsibility: a review of concepts, research and practice. International Journal of Management Reviews, (2010), 85-105.

Carroll, A.B. (1979). A three-dimensional conceptual model of corporate social performance. Academy of Management Review, 4(4), 497-505.

Devinney, T.M. (2009). Is the socially responsible corporation a myth? The good, the bad, and the ugly of corporate social responsibility. Academy of Management Perspectives, May 2009, 44-56.

Dubbink, W. \& van Liederkercke, L. (2009). A neo-kantian foundation of corporate social responsibility." Ethical Theory and Moral Practice 12, 117-136.

Friedman, M. (1962). Capitalism and freedom. Chicago. University of Chicago Press.

Galpin, T. \& Hebard, J. (2015). Sustainability in start-up ventures: what founders say versus what they do. World Journal of Entrepreneurship, Management and Sustainable Development, 11(4), 246-255.

Gökkaya, Ö. \& Özbağ, G.K. (2015). Linking Core Competence, Innovation and Firm Performance. International Journal Of Business Research Turk, 7/1, 90-102.

Habek, P. \& Wolniak, R. (2013). Analysis of approaches to CSR reporting in selected European Union countries. Journal of Economics and Research, 4(6), 79-95.

Hitt A.H. et al. (2003). Strategic Management. Competitiveness and Globalization. Cengage Learning EMEA, Andover.

Høgevold, N.M. et al. (2014). Sustainable business models: corporate reasons, economic effects, social boundaries, environmental actions and organizational challenges in sustainable business practices. Baltic Journal of Management, 9(3), 357-380.

Mao, W., Pearce, J.A. \& Reed Wasson, R. (2015). Profits and corporate philanthropy: an economic rationale for dual mission firms. Managerial and Decision Economics, 36, 439-455.

McWilliams, A. \& Siegel, D. (2001). Corporate social responsibility: a theory of the firm perspective. Academy of Management Review, 26(1), 117-128.

Michelini, L. \& Fiorentino, D. (2012). New business models for creating shared value. Social responsibility Journal, $8(4), 561-577$.

Mintzberg, H. (1983). The case for corporate social responsibility. Journal of Business Strategy 4, 3-15.

Ostenwalder, A. \& Pigneur, Y. (2009). Business Model Generatie. Vakmedianet, Deventer.

Parrish, B.D. (2010). Sustainability-driven entrepreneurship: principles of organization design. Journal of Business Venturing, 25, 510-523.

Prahalad, C.K. \& Hamel, G. (1990). The Core Competence of the Corporation. HBR, May-June 1990, 79-90.

Rahman, S.A., Amran, A., Ahmad, N.H. \& Taghizadeh, S.K. (2014). GrameenPhone: Creating a win-win at the base of the pyramid in Bangladesh. Global Business and Organizational Excellence, 41-53. 
Reedy, E.J., Fairlie, R.W., Russell, J. \& Morelix, A. (2016). The Kauffman Index of Start-up Activity. The EwingMarion Kauffman Foundation.

Ries, E. (2011). Lean Startup. Redline Verlag, München.

Shafer, S.M., Smith, H.J. \& Linder, J.C. (2005). The power of business models. Business Horizons 48, 199-207.

Strugatch, W. (2011). Turning values into valuation: can corporate social responsibility survive hard times and emerge intact? Journal of Management Development, 30(1), 44-48.

Teece, D.J. (2010). Business Models, Business Strategy and Innovation. Long Range Planning 43, 172-194.

Trimi, S. \& Bergebal-Mirabent, J. (2012). Business model innovation in entrepreneurship. International Entrepreneur Management, 8, 449-465.

Yunus, M., Moingeon, B. \& Lehmann-Ortega, L. (2010). Building Social Business Models: Lessons from the Grameen Experience. Long Range Planning 43, 308-325. 